\title{
SIMULASI MODEL SISTEM DINAMIS RANTAI PASOK KENTANG DALAM UPAYA KETAHANAN PANGAN NASIONAL
}

\author{
Muhammad Aminudin*, Akhmad Mahbubi**, Rizki Adi Puspita Sari**
}

\begin{abstract}
ABSTRAK
Tujuan penelitian yaitu; Mengidentifikasi sistem dasar rantai pasok dan permasalahan pada agribisnis kentang serta mengetahui sistem dan formulasi model rantai pasok kentang untuk pencapaian dalam ketahanan pangan nasional, Mengetahui perilaku sistem rantai pasok kentang untuk 10 tahun kedepan dilihat dari aspek sosial, ekonomi dan lingkungan. Penelitian ini merupakan kombinasi antara riset eksplanatori dan riset kausal. Penelitian dilakukan dengan menerapkan simulasi sistem dinamik untuk mengetahui rantai pasok kentang dalam kurun waktu 10 tahun mendatang. Data sekunder yang digunakan berupa data time series. Yang bersumber dari instansi terkait. Pemodelan menggunakan pendekatan sistem dinamis dengan program powersim. Dari hasil penelitian diperoleh: (1) Sistem industri kentang nasional terdiri dari sub-sistem produksi, supplier/pasokan, dan konsumsi. Karena sangat dipengaruhi waktu, sehingga sistem indutri kentang nasional menjadi dinamis. Selain itu juga lintas sektoral karena meliputi berbagai institusi yang terkait. (2) Sub-sistem produsen, dipengaruhi oleh variabel-variabel antara lain luas areal tanam, alih fungsi lahan (konversi), perluasan areal tanam (ekstensifikasi), agroekosistem, jumlah hari orang kerja, luas panen, dan pendapatan rumah tangga. Sub-sistem pemasok, dipengaruhi oleh variabel-variabel antara lain produksi kentang, konsumsi rumah tangga, konsumsi industri, pendapatan industri, pendapatan rumah tangga dan total konsumsi. Pada sub-model konsumsi dapat dilihat dinamika perkembangan penduduk yang sangat berpengaruh terhadap permintaan kentang untuk konsumsi. Aktivitas agroindustri kentang meliputi kegiatan produksi kentang menjadi makanan olahan berbahan dasar kentang dan menyalurkannya kepada konsumen. (3) Perilaku sistem rantai pasok kentang untuk 10 tahun kedepan dilihat dari aspek sosial, ekonomi dan lingkungan (keberlanjutan) menggunakan skenario peningkatan produktivitas kentang dari 16,56 ton/ha menjadi 17,56 ton/ha.
\end{abstract}

Kata kunci : sistem dinamis, rantai pasok, manajemen, berkelanjutan 


\begin{abstract}
The objective of this study is to identify the basic system and the problems in the supply chain as well as to perceive the agribusiness system of potatoes and potato supply chain model formulation for outstanding achievement in national food security, to perceive the potato supply chain system behavior for the next 10 years from the aspects of social, economic and environmental. This study is a combination of research and research causal explanatory. The study is conducted by applying dynamic system simulation to find out the potato supply chain within the next 10 years. Secondary data are used in the form of time series data that are collected from the relevant authorities. Modeling uses dynamic systems approach through powersim program. Results show that (1) System consists of the national potato industry sub-systems of production, supplier / supply, and consumption. Because it is influenced time, so that the system becomes a dynamic national potato industries. In addition, it is cross-cutting because it encompasses various related institutions. (2) Subsystem of manufacturer is influenced by variables including planting area, land conversion, expansion of planting areas (extension), agro-ecosystem, number of person-days, harvested area, and household income. Sub-system of supplier is influenced by variables include potato production, household consumption, industrial consumption, industry income, household income and total consumption. In sub-model of consumption it can be seen a very dynamic development of the population which affects the demand for potatoes for consumption. Activities include production of agro-industry potato into potato-based processed food and distribute it to consumers. (3) Behavior of the potato supply chain system for the next 10 years from the aspects of social, economic and environmental (sustainability) scenarios in potato productivity increase of 16.56 tonnes/ha to 17.56 t/ha.
\end{abstract}

Keywords: dynamical systems, supply chain management, sustainable

\section{PENDAHULUAN}

Diversifikasi pangan merupakan salah satu upaya dukungan mewujudkan ketahanan pangan yang telah diprogramkan Kementerian Pertanian. Langkah ini merupakan realisasi dari pelaksanaan Undang-undang RI No. 18 Tahun 2012 tentang Pangan. Penganeka-ragaman pangan pada dasarnya diarahkan untuk mendukung terjaminnya ketersediaan pangan yang cukup, aman, bermutu, bergizi dan beragam, serta tersebar merata di seluruh wilayah Indonesia dan terjangkau oleh daya beli masyarakat. Upaya ini sangat penting untuk mengatasi masalah ketergantungan pada satu bahan pangan pokok (beras/padi) saja, salah satunya dengan diversifikasi berbasis hortikultura seperti komoditas kentang.

Kentang merupakan salah satu pangan utama dunia setelah gandum, jagung dan padi. Tingginya nilai gizi 
menyebabkan kentang banyak diproduksi di berbagai wilayah, termasuk daerah yang kurang produktif (Rubatzky dan Yamaguchi, 1998) seperti Indonesia. Kentang termasuk ke dalam 35 komoditas unggulan nasional yang mendapat prioritas pengembangan oleh pemerintah. Kentang tergolong bahan makanan yang kaya nutrisi dan semakin meningkat kebutuhannya. Kentang merupakan salah satu komoditas sayuran yang memiliki peran penting dalam pemenuhan kebutuhan pangan masyarakat dan perdagangan internasional dari sekian banyak komoditas pada subsektor hortikultura. Kentang termasuk sumber karbohidrat yang diketahui memiliki kandungan gizi tinggi. Bagian yang dapat dimakan dari kentang menurut kajian Neraca Bahan Makanan (NBM) adalah sebesar $84 \%$. Zat-zat gizi makanan yang terkandung dalam 100 gram kentang adalah kalori $62 \mathrm{kkal}$, protein 2,10 gram, dan lemak 0,2 gram, sehingga bisa dijadikan sebagai salah satu bahan diversifikasi pangan (Ditjen Hortikultura, 2013). Kebutuhan komoditi kentang meningkat setiap tahun terutama untuk rumah tangga dan industri. Kentang

selain sebagai sayur-mayur juga dimanfaatkan sebagai bahan baku industri pengolahan, sehingga produk olahan kentang mempunyai nilai lebih tinggi dan harga lebih mahal daripada hanya dimanfaatkan sebagai sayur-mayur. Meningkatnya kebutuhan disebabkan oleh meningkatnya jumlah penduduk, adanya pola makan dan diversifikasi pangan masyarakat Indonesia, serta memenuhi kebutuhan luar negeri.

\section{Dalam rangka pemerataan} ketersediaan pangan terdapat beberapa faktor yang mempengaruhi seperti faktorfaktor dalam produksi dan faktor-faktor permintaan, dimana keterkaitan antar faktor dalam upaya ketahanan pangan bersifat komplek, dinamis dan probabilistik. Perlu dilakukan suatu distribusi pangan melalui pengelolaan rantai pasok kentang yaitu pengelolaan terhadap aliran material dan informasi serta modal yang mengikutinya dari awal sampai akhir mata rantai agribisnis kentang untuk mengoptimalkan pemenuhan kebutuhaan setiap entitas didalam rantai pasok kentang. Upaya pengelolaan rantai pasok berjalan efektif dan efisien jika sistem dasar dan perilaku sistem rantai pasok kentang diketahui dengan baik dengan memperhatikan keberlanjutan baik dari aspek ekonomi, sosial dan lingkungan. Tujuan dari penelitian ini adalah; 1) Mengidentifikasi sistem dasar rantai pasok dan permasalahan pada agribisnis kentang dalam ketahanan pangan nasional, 2) Mengetahui sistem dan formulasi model rantai pasok kentang untuk pencapaian ketahanan pangan nasional, dan 3) Mengetahui perilaku sistem rantai pasok kentang untuk 10 tahun kedepan dilihat dari aspek sosial, ekonomi dan lingkungan.

\section{METODE PENELITIAN}

Penelitian ini merupakan kombinasi antara riset eksplanatori dan riset kausal yaitu kombinasi analisis data sekunder dan eksperimen. Riset ekploratori dengan analisis data sekunder untuk mengetahui situasi dan permasalahan kentang nasional, 
sedangkan riset kausal dengan eksperimen untuk mengetahui hubungan antar fenomena. Penelitian ini dilakukan dengan menerapkan simulasi sistem dinamik untuk mengetahui rantai pasok kentang dalam kurun waktu 10 tahun mendatang serta berorientasi pada aspek sosial, ekonomi dan lingkungan. Data yang digunakan dalam penelitian ini adalah data sekunder berupa data time series 10 tahun produksi kentang, Luas tanaman kentang, luas panen, produksi kentang, produktivitas kentang, konversi lahan, ekstensifikasi, penggunaan pestisida, harga kentang, konsumsi kentang, jumlah tenaga kerja (hari orang kerja), populasi penduduk Indonesia, pendapatan masyarakat Indonesia. Sumber data penelitian ini adalah instansi terkait, meliputi Badan Pusat Statistik, dan Kementerian Pertanian.

Pemodelan menggunakan pendekatan sistem dinamis dengan program powersim. Garis besar tahapan penyelesaikan permasalahan dengan pendekatan sistem dinamis; 1) Perumusan dan Pendefinisian Masalah, 2) Penyusunan Sistem Konseptual, 3) Formulasi Model, 4) Simulasi dan Validasi Model, dan 5) Analisis Kebijakan atau Keputusan dan Perbaikan. Uji validasi menggunakan mape dengan program microsoft excel, uji ini dapat digunakan untuk mengetahui kesesuaian data hasil prakiraan dengan data aktual.

$$
\text { MAPE }=\frac{1}{n} \sum \frac{\left|x_{m}-x_{d}\right|}{x_{d}} \times 100 \%
$$

Keterangan :

$\mathrm{Xm} \quad=$ Data hasil simulasi
$\mathrm{Xd} \quad=$ Data aktual

$\mathrm{n} \quad=$ Periode/banyaknya data

Kriteria ketepatan model dengan uji MAPE (Lomauro dan Bakshi, 1985 dalam Somantri, 2005) adalah :

$$
\begin{array}{ll}
\text { MAPE }<5 \% & : \text { Sangat tepat } \\
5 \%<\text { MAPE }<10 \% & : \text { Tepat } \\
\text { MAPE }>10 \% & : \text { Tidak tepat }
\end{array}
$$

\section{HASIL DAN PEMBAHASAN}

\section{Sistem Dasar Rantai Pasok Kentang dan Permasalahan pada Agribisnis Kentang}

Sistem industri kentang nasional terdiri dari beberapa sub-sistem, antara lain sub sistem produsen, pemasok dan konsumen. Masing-masing sub-sistem terdiri dari unsur-unsur atau elemen-elemen yang lebih spesifik dan sangat dipengaruhi oleh perkembangan waktu, sehingga sistem industri kentang nasional bersifat dinamis. Sistem industri kentang nasional juga lintas sektoral karena meliputi berbagai institusi yang terkait, seperti sub sistem konsumsi kentang terkait dengan masalah kependudukan dan pendapatan masyarakat sedangkan sub-sistem pasokan terkait dengan masalah luas lahan dan budidaya pertanian

Pasokan kentang nasional sangat tergantung pada luas panen tanaman kentang, sedangkan luas panen kentang tergantung pada luas tanam kentang oleh petani sebagai pemasok. Tingkat produksi kentang sangat dipengaruhi oleh kualitas 
bibit kentang yang dipakai. Tanaman kentang merupakan tanaman yang sangat sensitif terhadap kecukupan unsur hara dalam proses pertumbuhan dan pembuahannya, disisi lain penambahan luas lahan akan memperbesar kebutuhan akan pupuk, dan karena keterbatasan kemampuan petani menyediakan pupuk sesuai dengan anjuran. Pemakaian pestisida yang berlebihan menyebabkan tanaman pengganggu menjadi resisten terhadap pestisida, penambahan luas tanam akan meningkatkan jumlah penggunaan pestisida yang secara tidak langsung dapat menurunkan produktivitas tanaman kentang.

Produksi kentang di Indonesia masih sangat rendah jika dibandingkan dengan produksi kentang Eropa yang rata-ratanya mencapai 25,5 ton per hektar, produksi ratarata kentang di Indonesia hanya sekitar 16 ton per hektar. Beberapa kendala produksi kentang yang masih perlu ditangani diantaranya: mutu benih yang kurang baik (terinfeksi virus), teknologi bercocok tanam yang belum memadai, serta iklim yang kurang mendukung. Penanganan pasca panen yang kurang baik dapat menyebabkan kerusakan umbi kentang sebesar $2-10 \%$ serta menimbulkan bagian terbuang sekitar 10 persen. Beberapa kendala yang menyebabkan kurang berhasilnya usaha petani kentang adalah karena rendahnya kualitas bibit yang dipakai sedangkan untuk memperoleh bibit yang bebas virus sangat sulit, teknik bercocok tanamnya yang kurang baik.

\section{Konseptual Sistem dan Formulasi Model Rantai Pasok Kentang}

Model dinamis menggambarkan interaksi antar elemen yang menyusun sistem agribisnis kentang. Permasalahan ketersediaan kentang merupakan suatu permasalahan sistem yang cukup kompleks dengan melibatkan berbagai komponen, variabel di dalamnya yang saling berinteraksi dan terintegrasi. Ketersediaan kentang secara nasional dapat dipandang sebagai suatu masalah dinamika sistem yang berubah sepanjang waktu dan dipengaruhi oleh faktor-faktor yang juga bersifat dinamis. Tujuan pemodelan ketersediaan kentang ini adalah untuk melihat pola ketersediaan kentang di masa mendatang untuk meningkatkan ketahanan pangan nasional dengan berbagai alternatif pengembangan skenario yang sesuai dengan kondisi nyata.

Model dinamika sistem yang dikembangkan dibatasi pada hal-hal yang berkaitan dengan penyediaan (produksi) dan permintaan kentang. Model ini dibuat berdasar identifikasi permasalahan yang dituangkan ke dalam diagram sebab akibat (causal loop), diformulasikan dalam diagram alir (stock dan flow) dan disimulasikan dengan menggunakan software Powersim. Sistem ketersediaan kentang dibagi menjadi tiga sub sistem yaitu sub sistem produsen, sub sistem pemasok, dan sub sistem konsumen agar memudahkan dalam pemodelan. 
Gambar 1. Pemetaan Elemen Sistem Rantai Pasok Kentang

$\frac{\text { Produsen }}{\text { Produksi }} \rightarrow \frac{\text { Processor/Industri }}{\text { Pemasok }} \rightarrow \frac{\text { Konsumen }}{\text { Konsumsi }}$

a. Sub Sistem Produsen

Sub model produsen kentang dipengaruhi oleh variabel-variabel antara lain luas areal tanam, alih fungsi lahan (konversi), perluasan areal tanam (ekstensifikasi), agroekosistem, jumlah hari orang kerja, luas panen, dan pendapatan rumah tangga. Dibutuhkan pula konstanta sebagai input bagi model disamping variabel-variabel tersebut, sehingga memudahkan dalam modifikasi model apabila terjadi perubahan-perubahan yang sesuai dengan kondisi nyata. Konstanta tersebut antara lain pendapatan rumah tangga petani kentang, pestisida,hari orang kerja per hektar, pendapatan usahatani, persen ekstensifikasi, persen konversi dan produktivitas kentang.

\section{b. Sub Sistem Pemasok}

Sub sistem pemasok kentang dipengaruhi oleh variabel-variabel antara lain produksi kentang, konsumsi rumah tangga, konsumsi industri, pendapatan industri, pendapatan rumah tangga dan total konsumsi. terdapat processor/industri sebagai entitas utama yang mengolah hasil produksi kentang kemudian menyalurkannya ke konsumen. Konstanta pada sub sistem pemasok adalah harga kentang per kilogram dan industri kentang. Aktivitas yang dilakukan oleh agroindustri kentang meliputi kegiatan produksi kentang menjadi makanan olahan berbahan dasar kentang dan menyalurkannya kepada konsumen.

\section{c. Sub Sistem Konsumen}

Sub model konsumsi kentang sangat dipengaruhi oleh perilaku masyarakat dalam mengkonsumsi kentang. Sub model kebutuhan/konsumsi kentang dapat dilihat dinamika perkembangan penduduk yang sangat berpengaruh terhadap permintaan kentang untuk konsumsi. Dinamika model penduduk ini akan menghasilkan output berupa prakiraan jumlah penduduk di masa mendatang. Dinamika perkembangan penduduk dalam sub model ini terbentuk melalui interaksi antara variabel jumlah penduduk Indonesia dengan variabel laju pertumbuhan penduduk dan laju kematian penduduk yang membentuk sebuah loop. Semakin besar laju pertumbuhan penduduk per tahun maka semakin besar jumlah penduduk tahunan, sebaliknya semakin besar laju kematian penduduk maka semakin berkurang jumlah penduduk tahunan.

Formulasi model dengan diagram alir dan perumusan matematis. Diagram alir dibangun dengan menggunakan powersim. Formulasi model dirumuskan ke dalam bentuk matematis yang dapat mewakili sistem nyata. Formulasi model menghubungkan variabel- variabel yang telah diidentifikasi dalam model konseptual dengan bahasa simbolik. Formulasi model potato.sim dalam perangkat lunak Powersim dapat dilihat pada gambar 2. 
Gambar 2 menunjukkan hubungan causal loop yang terdiri atas elemen-elemen sistem penyusun rantai pasok kentang yang memiliki hubungan timbal balik antar anggota elemen. Hubungan timbal balik antar elemen dalam causal loop dapat berupa hubungan positif atau negatif. hubungan positif terjadi jika nilai suatu elemen mengalami peningkatan maka menyebabkan peningkatan pada nilai elemen yang lainnya, atau jika nilai suatu elemen mengalami penurunan maka akan menyebabkan nilai elemen yang lain menjadi turun. Sebaliknya hubungan causal negatif antara satu elemen dengan elemen lain terjadi apabila peningkatan nilai suatu elemen tertentu akan menyebabkan nilai elemen yang lain turun atau sebaliknya.

Validasi model potato.sim dilakukan dengan membandingkan keluaran model (hasil simulasi) dengan data aktual yang diperoleh dari sistem nyata (quantitative behaviour pattern comparison). Validasi model dilakukan terhadap data aktual yaitu data luas panen kentang dan produksi tahun 2003-2012. Perhitungan uji MAPE (Mean Absolute Percentage Error) yang dilakukan terhadap data luas panen kentang diperoleh nilai sebesar $\quad 3,17 \%$. Terdapat penyimpangan sebesar $3,17 \%$ antara hasil simulasi dengan data aktual. Berdasarkan kriteria ketepatan model nilai MAPE tersebut adalah dibawah 5\% sehingga dapat disimpulkan bahwa model sangat tepat dan dapat diterima. Data produksi kentang antara simulasi dengan data aktual juga divalidasi. Berdasarkan perhitungan dengan uji MAPE terhadap data produksi kentang tahun 2003 -2012 diperoleh nilai sebesar $3,65 \%$. Nilai tersebut kurang dari 5\% sehingga dapat disimpulkan bahwa model tepat dan dapat diterima.

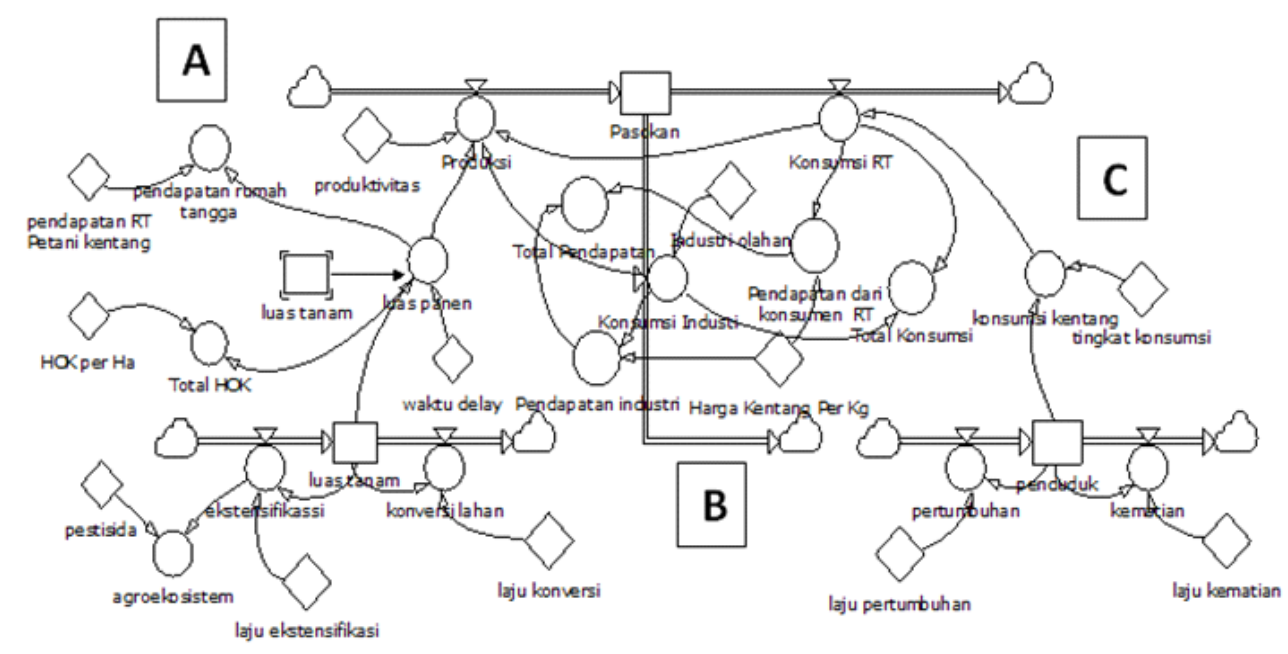

Keterangan : A : Produsen B :Pemasok C : Konsumen

Gambar 2. Model Supply Chain kentang di Indonesia 
Perilaku Sistem Rantai Pasok Kentang untuk 10 Tahun Kedepan

Pemodelan dinamika sistem ketersediaan kentang, rancangan model, simulasi dan analisis dilakukan dengan mengacu pada tujuan dan skenario pada setiap model. Beberapa skenario kebijakan yang akan digunakan dalam analisis perilaku Sistem rantai pasok kentang untuk 10 tahun ke depan baik dari aspek sosial, ekonomi dan lingkungan dengan berbagai skenario adalah sebagai berikut:

\section{a. Skenario Tanpa Perubahan Kebijakan}

Skenario ini diasumsikan sebagai hasil simulasi tanpa adanya kegiatan optimalisasi lahan (intensifikasi) maupun perluasan areal tanam (ekstensifikasi) dan peningkatan produksi kentang. Situasi ini menggambarkan ketidakaktifan pemerintah dalam mengatur penyediaan kentang dari dalam negeri di Indonesia. Dengan model ini dapat dianalisis situasi dan perilaku sistem penyediaan kentang di Indonesia tanpa adanya intervensi dari pemerintah. Berdasarkan hasil simulasi menunjukkan bahwa angka produksi kentang berimpitan dengan angka konsumsi kentang penduduk Indonesia. Pemerintah perlu meningkatkan produksi nasional ketang.

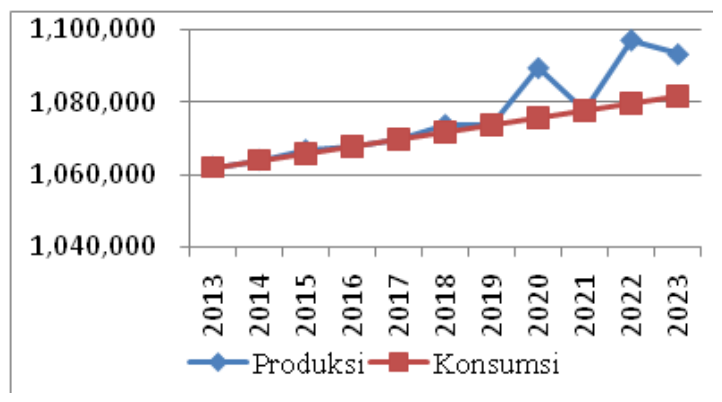

Gambar 3. Hasil Simulasi Produksi dan Konsumsi Kentang - Tanpa Perubahan Kebijakan

Hasil simulasi produksi dan konsumsi kentang dengan menggunakan software powersim menunjukkan peningkatan dari tahun ke tahun. Pada tahun 2013 produksi kentang sebesar 1.062.000 ton meningkat pada tahun berikutnya menjadi 1.073.734 ton. Konsumsi kentang 1.062 .000 pada tahun 2013 meningkat menjadi 1.081.670 pada tahun 2023. Peningkatan konsumsi kentang nasional dikarenakan perubahan pola konsumsi masyarakat Indonesia.

Produksi kentang terbesar akan terjadi pada tahun 2022 yaitu sebesar 1.097.105 ton. Anomali cuaca di musim kemarau berdampak buruk bagi produksi kentang di beberapa daerah di Indonesia.

\section{1) Aspek Sosial}

Aspek sosial yang dipertimbangkan adalah ketersediaan atau pasokan kentang untuk memenuhi permintaan konsumsi kentang. untuk melihat pememnuhan kebutuhan konsumen, dilihat perbandingan antar jumlah produksi kentang dengan jumlah permintaan. Penambahan jumlah tenaga kerja dilakukan untuk meningkatkan produksi kentang akibat perubahan pola konsumsi masyarakat akan kentang. Hasil simulasi menunjukkan bahwa produksi dan konsumsi kentang terjadi peningkatan dari tahun ke tahun. Peningkatan jumlah penduduk Indonesia dapat meningkatkan permintaan kentang dalam negeri. Hasil simulasi menunjukkan terjadi penambahan 
jumlah tenaga kerja pada tahun 2013 dari 19,2 juta menjadi 19,5 juta pada tahun berikutnya. Penambahan tenaga kerja terbanyak terjadi pada tahun 2023 yakni membutuhkan 19,8 juta hari orang kerja. Kemungkinan akan terjadi pengurangan tenaga kerja menjadi 19,1 juta pada tahun 2016 dari tahun sebelumnya akibat siklus iklim yang terjadi di Indonesia dari waktu ke waktu sulit diprediksi.

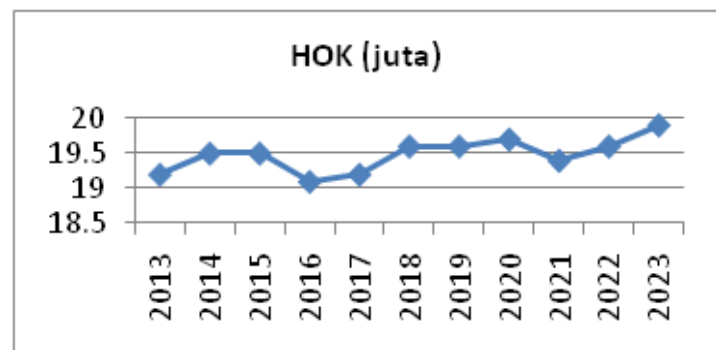

Gambar 4. Hasil Simulasi Hari Orang Kerja (HOK) - Tanpa Perubahan Kebijakan

\section{2) Aspek Ekonomi}

Pendapatan petani kentang diperoleh dari hasil penjualan kentang baik pendapatan dari penjualan ke luar negeri dan pendapatan dari pasar domestik. Pendapatan yang diperoleh dalam penjualan kentang cenderung mengalami peningkatan. dikarenakan permintaan dalam negeri yang terus meningkat akibat terjadinya perubahan pola konsumsi masyarakat dan penambahan penduduk Indonesia. Peningkatan produksi kentang dalam negeri dapat menambah jumlah tenaga kerja dengan adanya penambahan luas areal tanam kentang sehingga dapat mengurangi pengangguran. Pendapatan petani meningkat dari mulai Rp. 959 miliar pada tahun 2013 menjadi Rp. 973 miliar pada tahun 2014. Diperkirakan pendapatan rumah tangga petani kentang kentang akan mengalami peningkatan yang tertinggi yaitu pada tahun 2023 sebesar Rp. 993 miliar. Pendapatan terendah patani kentang terjadi pada tahun 2016 dimana terjadi penurunan pendapatan menjadi Rp. 956 miliar akibat dampak dari siklus iklim yang terjadi di Indonesia dari waktu ke waktu sulit diprediksi .

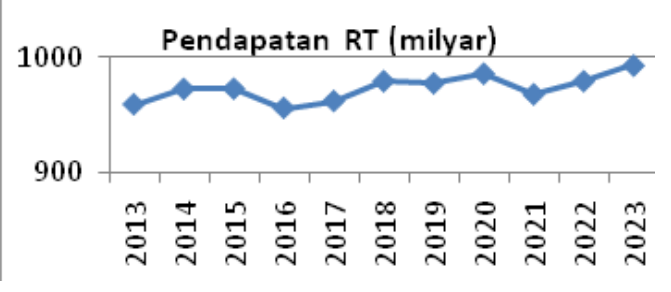

Gambar 5. Hasil Simulasi Pendapatan Rumah Tangga Kentang - Tanpa Perubahan Kebijakan

\section{3) Aspek Lingkungan}

Kenaikan pasokan kentang yang terus menerus mengindikasikan perluasan luas tanam kentang di Indonesia. Peningkatan luas tanam ini berdampak pada lingkungan yaitu terganggunya agroekosistem akibat penggunaan pestisida pada tanaman kentang. Pengelolaan agroekosistem seperti aplikasi pestisida sintetik dapat menurunkan species atropoda predator yang selanjutnya berakibat kelimpahan hama meningkat dan memperpendek rantai makanan karena komponen ekosistem di tingkat tropik yang lebih tinggi lebih rentan terhadap gangguan lingkungan. Akumulasi senyawa kimia (pestisida) terbukti mengganggu sistem reproduksi hewan ternak, sehingga jika dikonsumsi manusia berakibat kanker. Altieri dan Odum dalam 
Santosa (2005). Penggunaan pestisida berbahan kimiawi pada lahan pertanian kentang awal 2013 sebanyak 2.373 ton meningkat menjadi 2.380 ton pada tahun berikutnya. Penggunaan pestisida cenderung mengalami peningkatkan dari tahun ke tahun. Penggunaan pestisida terbanyak pada tahun 2023 sebesar 2.445 ton.

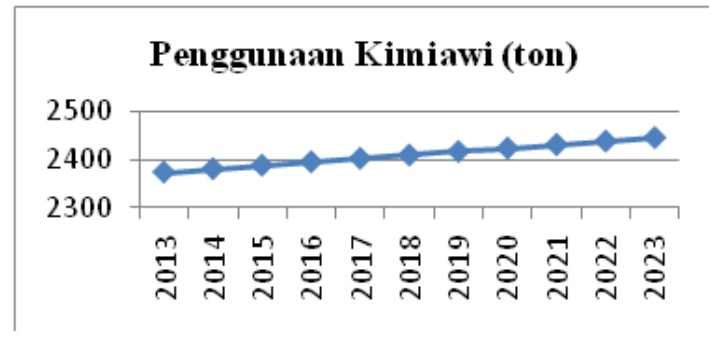

Gambar 6. Hasil Simulasi Pencemaran Agroekosistem - Tanpa Perubahan Kebijakan

a. Skenario Peningkatan Produktivitas Kentang dari 16,56 ton/ha menjadi 17,56 ton/ha

Peningkatan produktivitas kentang dilakukan dengan penerapan manajemen penanaman yang baik di sektor budidaya, mulai dari pemilihan bibit yang sehat, bertepatan pemilihan varietas dan masa tanamnya, pengolahan tanah, perawatan tanaman hingga pengangkutan ke gudang atau ke pasar. Skenario peningkatan produktivitas tanaman kentang sebesar 10 $\%$ diharapkan mampu mencukupi kebutuhan kentang dalam negeri. Berikut merupakan hasil simulasi produksi dan konsumsi kentang untuk 10 tahun ke depan.

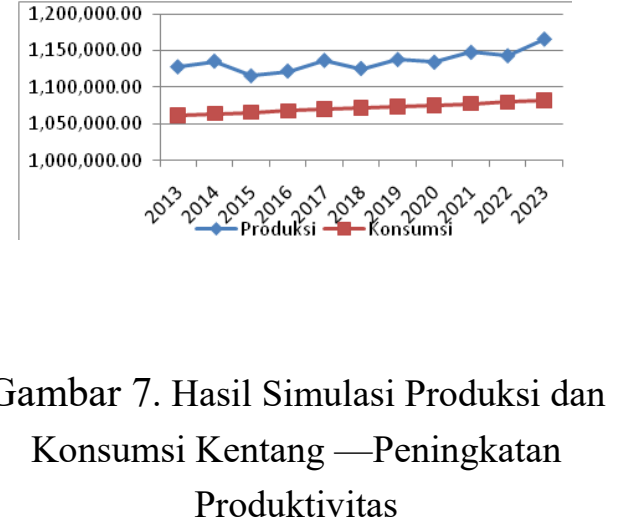

Permintaan kentang untuk konsumsi rumah tangga maupun konsumsi industri terus meningkat karena kentang dapat mensubstitusikan beras sebagai bahan makanan pokok. Prospek pengembangan agribisnis kentang sangat cerah. Di Indonesia kebutuhan konsumsi kentang diperkirakan meningkat dua kali lipat pada lima tahun sampai sepuluh tahun yang akan datang. Model yang dirancang menjelaskan skenario peningkatan produktivias kentang. Kebijakan peningkatan produktivitas tanaman kentang dengan meningkatkan produktivitas kentang dari 16,56 ton per tahun menjadi 17,56 ton per tahun, maka dalam jangka panjang upaya ketahanan pangan bisa tercapai. Peningkatan permintaan kentang menyebabkan peningkatan produksi dan perlu diadakannya peningkatan produktivitas kentang untuk memenuhi permintaan. Peningkatan produksi mengalami peningkatan tertinggi yakni pada tahun 2021 sebesar $1.147 .720,28$ juta ton dan 1.165.966,81 juta ton pada tahun 2023 . Konsumsi kentang dari tahun ke tahun mengalami peningkatan permintaan, baik untuk konsumsi rumah tangga maupun konsumsi untuk industri olahan akibat perubahan pola makan masyarakat. 


\section{1) Aspek Sosial}

Aspek sosial yang dipertimbangkan adalah ketersediaan pasokan untuk memenuhi konsumsi dan jumlah penambahan rumah tangga kentang atau jumlah tenaga kerja yang meningkat dengan ditingkatkannya produktivitas kentang dari tahun ke tahun. Peningkatan produktivitas kentang dapat menambah tenaga kerja di lahan pertanian dan peluang untuk mengentas pengangguran di daerah tersebut. Penambahan tenaga kerja terbanyak dari kebijakan peningkatan produktivitas terjadi pada tahun ke 9 yakni sebesar 19.6juta dan tahun ke 11 sebesar 19.9 juta karena pada tahun tersebut terjadi peningkatan produktivitas kentang yang cukup besar. Penambahan tenaga kerja paling sedikit terjadi pada tahun ke 3 yakni sebesar 19.1 juta hari orang kerja. Hal ini terjadi akibat peningkatan produktivitas pada tahun itu tidak sebesar tahun yang lainnya.

\section{2) Aspek Ekonomi}

Upaya peningkatan produksi dengan kebijakan peningkatan produktivitas kentang berdasarkan hasil simulasi untuk 10 tahun yang akan datang menunjukkan bahwa pendapatan yang dihasilkan dalam penjualan kentang fluktuatif. Angka pendapatan industri kentang tertinggi pada tahun ke-11 atau tahun 2023 sebesar 995 miliar rupiah. Pada tahun ke-3 atau tahun 2015 pendapatan industri kentang turun dari tahun sebelumnya menjadi 952 miliar rupiah. Pendapatan petani meningkat dari mulai Rp. 963 miliar pada tahun 2013 menjadi Rp 970 miliar pada tahun 2014 . Pendapatan terendah industri kentang terjadi pada tahun 2015 dimana terjadi penurunan pendapatan menjadi Rp. 953 miliar. Hasil simulasi pendapatan industri kentang dengan kebijakan peningkatan produktivitas menunjukkan peningkatan pendapatan tertinggi pada tahun 2023 yakni sebesar Rp. 996 miliar.

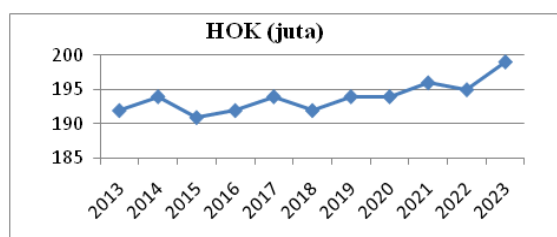

Gambar 8 Hasil simulasi Rumah Tangga Petani Kentang - Peningkatan Produktivitas

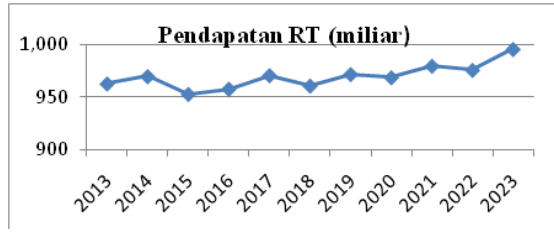

Gambar 9. Hasil Simulasi Pendapatan Industri Kentang - Peningkatan Produktivitas

\section{2) Aspek Lingkungan}

Kenaikan pasokan kentang yang terus-menerus mengindikasikan terjadinya peningkatan luas lahan kentang di Indonesia. Peningkatan produksi kentang didukung oleh luas lahan kentang yang menyediakan kentang segar dan bibit kentang. Peningkatan produktivitas bendampak pada lingkungan, dimana tingkat kesuburan tanah yang diindikasikan sebagai kerusakan lingkungan dikawasan lahan pertanian kentang. Kerusakan lingkungan akan semakin parah dan menjadi ancaman serius bagi kelangsungan 
hidup ekosistem yang ada jika kondisi tersebut tidak segera ditangani. Akibat peningkatan produktivitas dari 16,56 ton/ha menjadi 17,56 ton/ha per tahun, maka peluang terganggunya agroekosistem akibat aplikasi pestisida pada tanaman kentang semakin meningkat dari tahun ke tahun. Penggunaan pestisida berbahan kimiawi pada lahan pertanian kentang awal 2013 sebanyak 2.373 ton meningkat menjadi 2.380 ton pada tahun berikutnya. Penggunaan pestisida terus meningkat dari tahun ke tahun dan penggunaan pestisida sebanyak 2.445 ton pada tahun 2023 .

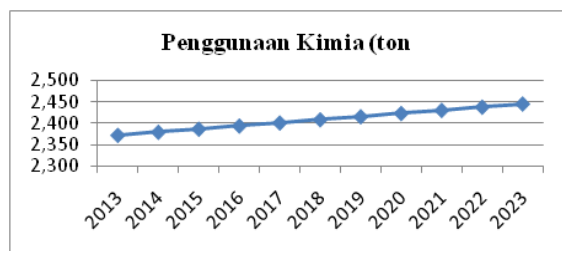

Gambar 10. Hasil Simulasi Pencemaran Agroekosistem - Peningkatan Produktivitas

\section{KESIMPULAN DAN SARAN}

\section{Kesimpulan}

1. Sistem industri kentang nasional terdiri dari beberapa sub-sistem, antara lain sub sistem produksi, supplier atau pasokan, dan konsumsi. Masing-masing sub-sistem terdiri dari unsur-unsur atau elemen-elemen yang lebih spesifik dan sangat dipengaruhi oleh perkembangan waktu, sehingga sistem industri kentang nasional bersifat dinamis. Sistem industri kentang nasional juga lintas sektoral karena meliputi berbagai institusi yang terkait, seperti sub sistem konsumsi kentang terkait dengan masalah kependudukan dan pendapatan masyarakat sedangkan sub-sistem pasokan terkait dengan masalah luas lahan dan budidaya pertanian.

2. Sub sistem produsen, dipengaruhi oleh variabel-variabel antara lain luas areal tanam, alih fungsi lahan (konversi), perluasan areal tanam (ekstensifikasi), agroekosistem, jumlah hari orang kerja, luas panen, dan pendapatan rumah tangga. Disamping variabel-variabel tersebut, dibutuhkan pula konstanta sebagai input bagi model sehingga memudahkan dalam modifikasi model apabila terjadi perubahanperubahan yang sesuai dengan kondisi nyata. Konstanta tersebut antara lain pendapatan rumah tangga petani kentang, pestisida, hari orang kerja per hektar, pendapatan usahatani, persen ekstensifikasi, persen konversi dan produktivitas kentang. Sub sistem pemasok, dipengaruhi oleh variabel-variabel antara lain produksi kentang, konsumsi rumah tangga, konsumsi industri, pendapatan industri, pendapatan rumah tangga dan total konsumsi. Sub sistem konsumen, konsumsi kentang sangat dipengaruhi oleh perilaku masyarakat dalam mengkonsumsi kentang. Pada sub model kebutuhan konsumsi dapat dilihat dinamika perkembangan penduduk yang sangat berpengaruh terhadap permintaan kentang untuk konsumsi. Aktivitas yang dilakukan oleh agroindustri kentang meliputi kegiatan produksi kentang menjadi 
makanan olahan berbahan dasar kentang dan menyalurkannya kepada konsumen.

3. Formulasi model dengan diagram alir dan perumusan matematis melibatkan 15 persamaan matematis. Perilaku sistem rantai pasok kentang untuk 10 tahun kedepan dilihat dari aspek sosial, ekonomi dan lingkungan (keberlanjutan) menggunakan skenario peningkatan produktivitas kentang dari 16,56 ton/ha menjadi 17,56 ton/ha.

\section{Saran}

1. Pemerintah perlu mendorong peningkatan produktivitas kentang antara lain melalui pengembangan metode budidaya kentang dan ketersediaan benih yang berkualitas.

2. Perlu adanya kajian resiko pasokan kentang nasional.

\section{DAFTAR PUSTAKA}

Badan Pusat Statistik. 2013. Luas Lahan, Produksi dan Produktivitas kentang tahun 2003-2012. Badan Pusat Statistik. Jakarta.

Daalen, V., and W.A.H. Thissen. 2001. Dynimics Systems Modelling Continuous Models. Faculteit Techniek, Bestuur en Management (TBM). Technische Universiteit Delft.

Direktorat Jenderal Hortikultura. 2013. Statistik Hortikultura Tahun 2013
(Angka Tetap), Kementerian Pertanian. Jakarta.

Kementerian Pertanian. 2012. Laporan Kinerja Kementrian Pertanian Tahun 2011. Kementrian Pertanian. Jakarta.

Kementerian Pertanian 2009. Kinerja Perdagangan Komoditas Pertanian. Direktorat Pemasaran Domestik Direktorat Jenderal Pengolahan dan Pemasaran Hasil Pertanian. Direktorat Perbenihan Hortikultura. Jakarta

Muhammadi, E. Aminullah, dan B. Soesilo. 2001. Analisis Sistem Dinamis Lingkungan Hidup, Sosial, Ekonomi, dan Manajemen. UMJ Press, Jakarta.

Santosa, E. 2005. Pemanfaatan Parasitoid dan Predator Dalam Pengendalian Hama Utama Padi Secara Berkelanjutan dalam buku : Prospek dan Tantangan Pertanian Indonesia Di Era Globalisasi. PT. Agricon. Bogor.

Somantri, A.S., E.Y Purwani dan Ridwan Thahir. 2005 Simulasi Model Dinamik Ketersediaan Sagu Sebagai Sumber Karbohidrat Mendukung Ketahanan Pangan Kasus Papua. Makalah. Balai Besar Pasca Panen Bogor.

Tasrif, M. 2004. Model Simulasi Untuk Analisis Kebijakan : Pendekatan

Metodologi System Dynamics. Kelompok Peneliti dan Pengembangan Energi. Institut Teknologi Bandung.

Widodo,K.H., Abdullah, A., Pramudya, K., dan Pujawan, Nyoman. Prof. D.R. 2010. Supply Chain Management 
Agroindustri yang berkelanjutan.

Lubuk Agung. Bandung.

www.bps.go.id/ (2013). Diunduh pada tanggal 15 September 2013 pukul 20.10 WIB. www.bps.go.id/ (2011) Diunduh pada tanggal 15 September 2013 pukul 20.12 WIB.

Yamaguchi, M., dan E.V. Rubatzky. 1998 Sayuran Dunia. Jilid I. Terjemah Catur H. ITB Press. Bandung.

*Alumni Program Studi Agribisnis dan **3Dosen Fakultas Sains dan Teknologi UIN Syarif Hidayatullah Jakarta 